IdeAs

Idées d'Amériques

16 | 2020

Les marges créatrices : intellectuel.le.s afrodescendant.e.s et indigènes auX Amériques, XIX-XXe siècle

\title{
Fractured America: How did we get here?
}

\section{Marc Hetherington and Jonathan Weiler}

\section{(2) OpenEdition}

\section{Journals}

Electronic version

URL: http://journals.openedition.org/ideas/9407

DOI: 10.4000/ideas.9407

ISSN: 1950-5701

\section{Publisher}

Institut des Amériques

\section{Electronic reference}

Marc Hetherington and Jonathan Weiler, « Fractured America: How did we get here? », IdeAs [Online], 16 | 2020, Online since 01 October 2020, connection on 18 October 2020. URL : http:// journals.openedition.org/ideas/9407 ; DOl : https://doi.org/10.4000/ideas.9407

This text was automatically generated on 18 October 2020

\section{$(\mathbb{\theta} \Theta \Theta$}

IdeAs - Idées d'Amériques est mis à disposition selon les termes de la licence Creative Commons Attribution - Pas d'Utilisation Commerciale - Pas de Modification 4.0 International. 


\title{
Fractured America: How did we get here?
}

\author{
Marc Hetherington and Jonathan Weiler
}

1 An August 2020 CBS Poll asked Americans whether they considered the number of fatalities from Covid-19 - then around 170,000 in the United States - acceptable. The vast majority of Americans, including $90 \%$ of Democrats, said it was not. But among Republicans, fully $57 \%$ did deem it acceptable, though many also wondered whether the number of deaths was being exaggerated. Regardless, the reporting of that poll was accompanied by widespread shock that so many Republicans could be so blasé about such extensive suffering and death, especially since the experience of most of the industrialized world made clear that a toll of that size was eminently preventable ${ }^{1}$.

2 This is one of countless data points that illustrate how deeply divided Americans are on the most basic political, social and cultural questions of our time. Even when it comes to objective conditions, Republicans and Democrats often see the world in fundamentally different ways. Indeed, the language most commonly used by political scientists to describe this divide, "political polarization" or "partisan polarization," has itself arguably become too bloodless to capture adequately the nature, intensity and consequence of the extraordinary rift in American society. All of that is happening in a context in which Americans on all sides believe that more is at stake in the 2020 election than any they can remember. For supporters of Donald Trump, America as they know it may be lost forever if he loses. For Trump's detractors, the very fate of American democracy is on the line.

\section{How did we get here?}

3 For most of the $20^{\text {th }}$ century, most scholars thought US politics generated only "low heat" because of its two-party system, in which parties had unique incentives to appeal to the political middle. We agree American politics of the $20^{\text {th }}$ century was mostly low heat, but we disagree about why. Instead the heat was low because the specific issues at the center of party contestation were not ones that especially stirred voters' passions. 
Until the 1960s, the main fault line in American politics was about the size of government and the Cold War conflict with the Soviet Union. Although race and racism have always been pervasive features of American life, they didn't express themselves in partisan political conflict through most of the $20^{\text {th }}$ century. Both parties were internally divided on these matters and reticent about addressing the roots of racism. As such, the parties mostly worked to downplay racial issues and instead focused on class-based appeals.

4 Beginning in the 1960s and accelerating in the decades that followed, racial issues and other moral and identity-based issues became the fault line that divided Republicans and Democrats. On race, for example, the Republican Party began to identify itself with skepticism of civil rights, connected to fear of growing crime and lawlessness. They appealed to blue collar workers - mostly Democrats at the time - by promising to impose law and order to ensure that these workers' neighborhoods would be safe from the ravages caused by liberal excesses and the racial tumult unfolding on their television sets in 1960s America.

5 Race was the first issue to open the new fault line, but it would soon be reinforced by several other issues. A series of monumental social changes, including the rise of feminism and changing family structures, the emergence of gay rights and marriage equality and the growing importance of terrorism, especially after the 9/11 attacks, all contributed to this newly reconfigured divide. These sorts of issues, we believe, prompt much more gut-level, instinctive "reasoning" than do questions of tax policy and the size of government, the sorts of issues that dominated politics for the first three quarters of the century.

6 As these gut level issues came to dominate our politics, Americans began to view the consequences of losing to the other side with growing alarm. What was at stake in losing an election wasn't whether your taxes might go up or down, though Americans certainly still fight over that. What was on the line, increasingly, was a fundamental clash over the most basic questions of right and wrong. When such deeply held, visceral differences become the foundation of politics, the stakes of losing increase dramatically.

7 For fifteen years now, we have been cataloguing, analyzing and trying to explain the fact, feel and significance of America's great divide. Reflecting back, it is striking that when we first wrote about it in 2005, the nature and depth of the divide would seem almost quaint by today's standards. What we have come to call the worldview divide was only then taking root. America saw no violence in the streets as we see on a regular basis today. Partisans disliked the other party, but they didn't hate them like they do now. The Republican standard bearer then, George W. Bush, tried to unify the country after 9/11. Donald Trump, the Republican standard bearer now, stokes division as soon as he gets out of bed each morning.

8 The chasm in American society has deepened and widened into areas of life that previously did not seem to merit political analysis. By now it's considered axiomatic that Democrats and Republicans are worlds apart. In fact, that increasingly even means where they prefer to live (more urban or more rural areas), what they prefer to eat (American food or ethnic cuisine), wear (traditional or fashionable) and drive (Prius or pickup truck) are all telling reflections of the divisions that have led many political analysts to believe that our country is more fractured than at any time since the end of America's Civil War in the $19^{\text {th }}$ century. 


\section{Human Psychology Intersects with Political Context}

To understand how Americans came to be so divided, it is necessary to understand the psychological constructs that they use to make sense of the world around them. As we have explicated above, real world politics has offered up a completely changed partisan context from fifty years ago. That is part of the story. Understanding polarization, however, also requires understanding how ordinary people make sense of this changed context, psychologically. We use the term worldview to capture the broad and instinctive frameworks people use to respond to and make sense of their surroundings. We begin from the premise that, in general, people react more or less fearfully, more or less suspiciously, and more or less openly to the world around us, based both on circumstances and on our predispositions.

We have found that how Americans (and in more recent work, not only Americans) answer four simple questions about how children ought to be raised, provides us with great insight into people's worldviews and, in turn, their politics. The four questions are paired choices, in which respondents are asked which trait is more desirable for children to have. All the qualities are good ones. People are thus forced to decide which ones to prioritize.

They are

- independence or respect for their elders;

13 - curiosity or good manners;

14 - self-reliance or obedience;

15 - being considerate or being well-behaved.

16 Historically, this battery of questions has been referred to as measuring "authoritarianism," a rather dark personality trait put forward by researchers in the 1940 s and 1950s to understand why people would follow Nazism. Much of the substance and the inspiration derives from the work of Theodore Adorno and associates in the classic postwar work, The Authoritarian Personality. These measures about child rearing update Adorno's early work on the subject. Those who prefer independence, curiosity, being considerate and self-reliance are less authoritarian. Those who say children should respect elders, be obedient, display good manners and be well-behaved are considered more authoritarian.

17 In our 2018 book, Prius or Pickup, we substituted the terms fixed worldview and fluid worldview for authoritarian and nonauthoritarian. One reason for this change was to avoid the pejorative connotations of the older language, though the relationship between authoritarianism in the parenting questions and support for the increasingly apparent authoritarian designs of President Trump is undeniable. Our thinking also derived in part from the manner in which our analysis extended from strictly political questions - like whether someone supported restricting immigration or opposed same sex marriage - to broader lifestyle questions, like what kinds of places people like to live or what cars people prefer to drive. Clearly the present-day political divide turns on something far broader than whether a person is more or less likely to succumb to an authoritarian style leader. The term worldview captures that breadth much better. 

worldview styles and how it matters. Americans were asked which of two visions of the world was closer to their own. One, that "the world is a big beautiful place, mostly full of good people who we must find a way to embrace each other". The other, that "our lives are threatened by terrorists, criminals and immigrants and that we must defend ourselves" against them. On the one side is outward looking understanding of the world, and on the other is a much darker view - American carnage to some. Not surprisingly, roughly $80 \%$ of Clinton voters said the former came closer to their view of the world. An equal proportion of Trump voters said the latter did.

The events of the last number of months illustrate further this worldview divide and how it will express itself electorally. The US has been riven by racial violence across many cities since the Spring. Rather than trying to quell the racial unrest, which was brought on by unwarranted police violence against people of color, Republicans seem invested in fanning the flames. They believe that more disorder and chaos will cause swing voters to recognize that their worldview best characterizes the needs of the country. The country does not need to change. Racial and ethnic minorities need to 
change. Democrats, in contrast, champion the cause of minority groups. They believe that the country needs to change to overcome racial inequalities that have persisted for centuries.

But this divide is about more than race, and it is about more than the coming election. A worldview divide fundamentally pits the forces of tradition against the forces of innovation, whether that is about race, gender, sexual orientation, or something else. It embodies a philosophy about how to live life more than it embodies a philosophy about how to manage politics. That is a polarizing basis for political conflict to be sure.

Maybe more important the process of sorting by worldview has created a peril for our institutions and for civil order that was not previously likely. Donald Trump did not cause the worldview divide; it had been in place for a decade or more before he emerged. But it makes the country more vulnerable to someone like Trump, who has often expressed sentiments quite antithetical to democracy. Because the stakes are so high and because the vision the other side presents seems so antithetical to basic moral values, behaviors that seemed previously to violate accepted norms of politics become justifiable, even necessary, to maintain the "greatness" of the nation's past. If the other side is so dangerous, so bereft of basic character and decency, playing by the rules becomes a luxury decent people cannot afford.

No modern political figure has framed the stakes in such stark terms as Trump. His supporters may not hunger for authoritarian rule on its own. But they are perfectly ready to believe that any actions to stem the threat liberals pose are acceptable. Likewise, liberals see in Trump a mortal threat to our social and political fabric. Disagreement on specific issues, though those are loud and intense, scarcely matter. It is the nature and character of the man, and his supporters that is so shocking and horrifying. Only a politics whose foundation is itself so anchored in gut level psychology could engender this state of affairs.

\section{NOTES}

1. https://www.cbsnews.com/news/republicans-economy-coronavirus-opinion-poll-cbs-newsbattleground-tracker/ 


\section{AUTHORS}

\section{MARC HETHERINGTON}

Marc Hetherington est Raymond Dawson Bicentennial Professor à l'Université de Caroline du Nord à Chapel Hill. Il a notamment cosigné avec Jonathan Weiler Prius or Pickup: How the Answers to Four Simple Question Explain America's Great Divide (Houghton Mifflin Harcourt, 2018).

\section{JONATHAN WEILER}

Jonathan Weiler est Teaching Professor and Associate Chair of the Curriculum in Global Studies à l'Université de Caroline du Nord à Chapel Hill. Il a notamment cosigné avec Marc Hetherington Prius or Pickup: How the Answers to Four Simple Question Explain America's Great Divide (Houghton Mifflin Harcourt, 2018). 